\title{
Screening of Methyl Red Degrading Bacteria Isolated from Textile Effluents of Savar Area, Dhaka, Bangladesh
}

\section{Ishteak Ahmed1, Farhana Haque1, Mirza A. T. M. Tanvir Rahman², Md. Anowar Khasru Parvez¹, Taslin Jahan Mou'}

\author{
${ }^{1}$ Department of Microbiology, Jahangirnagar University, Savar, Bangladesh \\ ${ }^{2}$ Department of Environmental Sciences, Jahangirnagar University, Savar, Bangladesh \\ Email: moumicro@juniv.edu
}

How to cite this paper: Ahmed, I., Haque, F., Rahman, M.A.T.M.T., Parvez, Md.A.K. and Mou, T.J. (2020) Screening of Methyl Red Degrading Bacteria Isolated from Textile Effluents of Savar Area, Dhaka, Bangladesh. Advances in Bioscience and Biotechnology, 11, 301-318.

https://doi.org/10.4236/abb.2020.117022

Received: May 17, 2020

Accepted: July 14, 2020

Published: July 17, 2020

Copyright $\odot 2020$ by author(s) and Scientific Research Publishing Inc. This work is licensed under the Creative Commons Attribution International License (CC BY 4.0).

http://creativecommons.org/licenses/by/4.0/

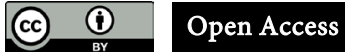

\begin{abstract}
Physicochemical properties and metal contents of five dye-based textile effluents collected in summer and winter season, 2016 from Savar, Dhaka, Bangladesh were within the recommended acceptable limit. The average value of all physicochemical parameters was found high in summer season except turbidity. A total of 94 heavy metal resistant bacteria ( 46 gram positive \& 48 gram negative) were isolated from textile effluent samples and among them 17 isolates were multi metal resistant. Highest tolerance level of the isolates was shown at $10 \mathrm{mM}$ concentration against $\mathrm{Pb}$. All the heavy metal resistant bacterial isolates were presumably grouped into 14 genera according to morphological and biochemical assay. Three isolates designated WFB3c (65.41\%), WFB4g (62\%) and SFB5c (60.07\%) were found to potentially degrade dye as well as tolerate heavy metals. Three potential dye decolorizer isolates were screened out and most potential one (WFB3c) was identified as Proteus mirabilis according to the $16 \mathrm{~S}$ rRNA identification. The isolated bacterial strain Proteus mirabilis would be a potential candidate for microbes based treatment to decolorize dye from textile effluents.
\end{abstract}

\section{Keywords}

Textile Effluent, Metal Resistant, Dye Decolorizer, Proteus mirabilis

\section{Introduction}

Pollution of the natural environment by heavy metals is a worldwide anxiety because of their toxic effects on living organisms and non-biodegradable nature upon exceeding a certain concentration [1]. In soil and aquatic environment, 
heavy metal contamination is also one of the critical concerns in Bangladesh [2]. As with the passage of time around all over Dhaka city there is increasing number of industries. Savar is one of the largest industrial belts and Dhaka export processing zone (DEPZ) is also located at Savar. The most of the industries in Savar area include garments, textile miles, leather goods, metal products, electronic goods, paper products, chemicals and fertilizers and miscellaneous products [3]. Industries within these areas release a huge amount of effluents containing heavy metals, toxic chemicals, hydrogen sulfide, sulfuric acid, dyes. bleach, formic acid, oil, suspended solids, organic matter, pesticides, polychlorinated biphenyls (PCBs), dioxins etc. [4]. Among the industries, textile industries generate huge amounts of effluents containing considerable amounts of suspended solids, additives, detergents, surfactants, carcinogenic amines, aldehydes, heavy metals and dyes [5]. The indiscriminate release of heavy metals into the soil and water is one of the major health concerns, since even at their low concentrations they are very toxic (arsenic, cadmium, chromium, copper, lead, mercury, nickel, selenium, silver, zinc etc.) and cannot be broken down to their non-toxic forms, resulting in long lasting effects on the ecosystem [6].

Dye based textile industries are also one of the major sources of pollution [7]. Textile industries consume a large volume of azo dyes whereas up to $50 \%$ of dyes find their ultimate way in the water as effluents [8]. Moreover, most of these dyes have potentially toxic effect on aquatic lives and some are even carcinogenic and mutagenic to humans [9]. Textile azo dyes are most often found difficult to degrade completely, and the conventional physico-chemical treatment processes are not always preferable enough for their complete degradation and conversion to $\mathrm{CO}_{2}$ [10]. Some characteristics of these dyes like toxicity, mutagenicity and stability to light and temperature inhibit attack by microorganisms. Permanent decolorization and biodegradation is only possible upon cleavage and reduction of azo bonds respectively. So removal of such dyes is a matter of great concern [11]. Therefore, industrial effluents containing azo dyes before discharging into the environment must be treated to remove the dye toxicity from textile effluent [12]. Methods such as adsorption, chemical precipitation, and flocculation have substantial disadvantages that contain complex structural set-up, huge chemical and power consumption and formation of a large volume of sludge [13]. In contrast, it has been proved that bioremediation of dyeing industrial effluents through microbial activities would be the best solution [14].

These possible environmental application (detoxification of toxic heavy metal and decolorization of textile dyes) generated present interest to screen out the metal resistant and dye decolorizing microbes those survive in the contaminated site and its characterization to prove it further for its suitability for bioremediation of heavy metal \& textile dye degradation of contaminated site.

\section{Methodology}

\subsection{Study Area and Sample Collection}

Samples were collected in both winter (February) and summer (May) season, 
2016 from 5 different outlets of 5 different textile industries, located in Savar area within latitude 23.8334 and longitude 90.266670. Sample were collected in sterile plastic bottle and acidified and aseptically transported to laboratory in an ice pack and temperature was maintained at $4^{\circ} \mathrm{C}$ until further work.

\subsection{Determination of Physicochemical Parameters}

Physicochemical parameters such as temperature, electric conductivity (EC), total dissolved solids (TDS), total suspended solids (TSS), turbidity, $\mathrm{pH}$, dissolved oxygen (DO), biological oxygen demand (BOD), and chemical oxygen demand (COD) of the textile effluent was also determined by standard methods (APHA) in both seasons [3]. The temperature of the effluent samples was determined by mercury thermometer graduated $0^{\circ} \mathrm{C}$ to $100^{\circ} \mathrm{C}$. $\mathrm{pH}$ was determined by the electrometric method by using glass electrode $\mathrm{pH}$ meter (SCHOTT instrument). Similarly, TDS and TSS were analyzed by the gravimetric method by TDS meter (Model HANNA HI 8734) and by using evaporating dishes and Whatman filter paper having pore size $11 \mu \mathrm{m}$. The COD test and $\mathrm{BOD}_{5}$ were analyzed by modified Winkler's method in $300 \mathrm{~mL}$ BOD bottles. Other parameters such as turbidity, DO and EC were also determined with the microprocessor turbidity meter, DO meter (970 $\mathrm{DO}_{2}$ meter, Serial \# 20600, Jenway UK) and EC meter (HANNA, EC 241 Conductivity meter) respectively. Presence of different heavy metal $(\mathrm{Pb}, \mathrm{Ni}, \mathrm{Cd} \& \mathrm{Cu})$ content was also measured by using atomic absorption spectrophotometer (AAS) (APHA).

\subsection{Bacterial Isolation and Total Viable Count}

Bacteria were isolated through serial dilution of the textile effluents in normal saline after that, plated onto nutrient agar (NA) medium. The plates were incubated at $37^{\circ} \mathrm{C}$ for 24 hours in an incubator. The following day, colonies were counted as $\mathrm{cfu} / \mathrm{ml}$ and morphologically distinct colony was sub cultured for purification and also gram's staining was performed [15]. Isolated strains (500 $\mu$ l of growing culture) were kept at $-20^{\circ} \mathrm{C}$ in nutrient broth medium containing $500 \mu$ glycerol.

\subsection{Biochemical Characterization of the Isolated Strains}

Various biochemical test such as, KIA (Kligler's Iron Agar), indole test, Methyl red test, Voges-Proskauer (VP) test, Citrate utilization test, oxidase test, catalase test were performed by the methods described in "Microbiology: A Laboratory Manual" to characterize the isolated bacterial strain [15].

\subsection{Metal Tolerance Test}

Metal tolerance test was performed to screen metal resistant bacteria. To serve this purpose, toxic form of different heavy metal such as lead nitrate $\left[\left(\mathrm{PbNO}_{3}\right)_{2}\right]$, nickel chloride hexahydrate $\left(\mathrm{NiCl}_{2} \cdot 6 \mathrm{H}_{2} \mathrm{O}\right)$, cadmium sulphate hydrate $\left(3 \mathrm{CdSO}_{4} \cdot 8 \mathrm{H}_{2} \mathrm{O}\right)$ and Copper sulphate pentahydrate $\left(\mathrm{CuSO}_{4} \cdot 5 \mathrm{H}_{2} \mathrm{O}\right)$ were used. All the group representative isolated bacterial strains were streaked onto Luria 
Bertani (LB) medium supplemented with different toxic form of these metal at various concentration ( $1 \mathrm{mM}, 3 \mathrm{mM}, 5 \mathrm{mM}, 8 \mathrm{mM} \& 10 \mathrm{mM})$ and incubated at $37^{\circ} \mathrm{C}$ for 72 hours [16].

\subsection{Fisher Exact Test}

Fisher exact test implies the significance if there are associations between two categorical variables. The test was performed to determine the statistical significance of our analysis of heavy metal tolerance of the bacterial isolates in winter and summer season.

\subsection{Azo Dye Decolorization Assay}

In this study methyl red dye was used as a model azo dye. Dye decolorization activity was demonstrated as percentage of decolorization using UV-spectrophotometer. Culture media that was used to determine decolorization activity composed of (g/l); Peptone 5; Yeast extract 3; Beef extract 2; $\mathrm{NaCl} 5 ; \mathrm{K}_{2} \mathrm{HPO}_{4}$ 5; $\mathrm{KH}_{2} \mathrm{PO}_{4} 1 ; \mathrm{MgSO}_{4} \cdot 7 \mathrm{H}_{2} \mathrm{O}$ 0.10. All the isolates were inoculated into that broth media supplemented with $1 \%$ methyl red and kept in a mechanical shaker (150 $\mathrm{rpm}$ ) at $37^{\circ} \mathrm{C}$ for 48 hours. uninoculated culture media with methyl red dye was served as a control. After two days aliquots were withdrawn and centrifuged at $10,000 \mathrm{rpm}$ for 10 minutes at room temperature. Equation (1) is the percentage (\%) of dye decolorization and absorbance of the supernatant was taken at 410 $\mathrm{nm}$ for each sample as well as control to measure,

$$
\% \text { of dye decolorization }=\frac{\text { Initial absorbance }- \text { final absorbance }}{\text { Initial absorbance }} \times 100
$$

\subsection{Molecular Characterization}

DNA were extracted through boiling methods. $16 \mathrm{~s}$ region of the ribosomal rRNA gene were identified by using universal primer 8F (5-AGT TTG ATC CTG GCT CAG-3) and 1492R (5-ACC TTG TTA CGA CTT-3) [17]. PCR amplification was performed according to following conditions: initial heating at $96^{\circ} \mathrm{C}$ for 5 minutes followed by 35 cycles of denaturation at $94^{\circ} \mathrm{C}$ for 30 seconds, annealing at $50^{\circ} \mathrm{C}$ for 30 seconds, extension at $72^{\circ} \mathrm{C}$ for 45 seconds and final extension of 10 minutes at $72^{\circ} \mathrm{C}$. The PCR mixture contained $1 \times$ PCR buffer, 2.50 $\mathrm{mM} \mathrm{MgCl} 2,0.20 \mathrm{mM}$ dNTP, $10 \mathrm{pmol}$ of each primer, $2 \mu \mathrm{l}$ template DNA and $1.25 \mu \mathrm{l} \mathrm{Taq}$ DNA polymerase, in a final volume of $20 \mu \mathrm{l}$. The amplified 16S rRNA genes were purified using Wizard PCR SV Gel and PCR Clean-Up System kit (Promega) in accordance with the directions of the manufacturer. The sequence was generated from the purified 16S rRNA gene using the Applied Biosystem Integrated-310 (Thermo Fisher Scientific) according to the manufacture's instruction. Partial sequence were compared to GenBank database of the National Center for Biotechnology Information (NCBI)

(http://www.ncbi.nlm.gov/GenBank) by means of the basic local alignment search tool (BLAST) to identify close phylogenetic relatives. The sequence was depo- 
sited into gene bank and aligned with the Clustal W software [18].

\section{Results}

\subsection{Physicochemical Parameter and Heavy Metal Content of Textile Effluent Samples}

A total of ten samples were collected from five different sampling sites during both winter and summer season and various physicochemical parameters were determined (Table 1). The temperature profile of the effluent varied significantly in both seasons and ranged from $26.2^{\circ} \mathrm{C}$ to $26.8^{\circ} \mathrm{C}$ during winter; $32.5^{\circ} \mathrm{C}$ to $33.3^{\circ} \mathrm{C}$ during summer. The EC of effluent flowing in the winter season were found to vary in the range $903(\mu \mathrm{s} / \mathrm{cm})$ to $1259(\mu \mathrm{s} / \mathrm{cm})$ and that of summer were $789(\mu \mathrm{s} / \mathrm{cm})$ to $1159(\mu \mathrm{s} / \mathrm{cm})$. Total suspended solids (TSS) is the particles dry-weight trapped through a filter. In our study TSS in winter season was found in the range $210 \mathrm{mg} / \mathrm{L}$ to $885 \mathrm{mg} / \mathrm{L}$ and in summer that was $165 \mathrm{mg} / \mathrm{L}$ to 850 $\mathrm{mg} / \mathrm{L}$. Total dissolved solids was found in range of 210 to $300 \mathrm{mg} / \mathrm{L}$ and 290 $\mathrm{mg} / \mathrm{L}$ to $310 \mathrm{mg} / \mathrm{L}$ in winter and summer water respectively. Seasonal variation in the value of turbidity was measured and found in the range from 34.30 to 145.26 FTU during winter and 11.02 to 260 FTU during summer. The $\mathrm{pH}$ ranged from 7.18 to 7.94 during winter and 7.02 to 7.52 during summer. The DO value in winter season was found from $5.54 \mathrm{mg} / \mathrm{L}$ to $6.43 \mathrm{mg} / \mathrm{L}$ and $3.98 \mathrm{mg} / \mathrm{L}$ to $4.50 \mathrm{mg} / \mathrm{L}$ in summer. The COD parameter is a measurement of the organic matter that present in water. The maximum value of COD in winter season was found to be $286 \mathrm{mg} / \mathrm{L}$ and minimum value was $139 \mathrm{mg} / \mathrm{L}$ and in summer the maximum value was $1371 \mathrm{mg} / \mathrm{L}$ and the minimum value was $473 \mathrm{mg} / \mathrm{L}$. The BOD value was found in the range from $0.22 \mathrm{mg} / \mathrm{L}$ to $1 \mathrm{mg} / \mathrm{L}$ during winter season and $2 \mathrm{mg} / \mathrm{L}$ to $4.04 \mathrm{mg} / \mathrm{L}$ during summer season. In the winter season $\mathrm{Pb} \&$ $\mathrm{Ni}$ was found and in the summer season $\mathrm{Cu} \& \mathrm{Ni}$ was found.

\subsection{Total Viable Bacterial Count of the Sample}

TBVC is one of the significant parameters for determining water quality. The

Table 1. Physico-chemical parameter analysis of textile effluent samples.

\begin{tabular}{|c|c|c|c|c|c|c|c|c|c|c|c|c|c|c|}
\hline & $\begin{array}{l}\text { Sample } \\
\text { ID }\end{array}$ & $\begin{array}{c}\text { Temp } \\
\left({ }^{\circ} \mathrm{C}\right)\end{array}$ & $\begin{array}{c}\text { EC } \\
(\mu \mathrm{s} / \mathrm{cm})\end{array}$ & $\begin{array}{l}\text { TDS } \\
(\mathrm{mg} / \mathrm{l})\end{array}$ & $\begin{array}{c}\text { TSS } \\
(\mathrm{mg} / \mathrm{l})\end{array}$ & $\begin{array}{c}\text { Turbidity } \\
\text { (FTU) }\end{array}$ & $\mathrm{pH}$ & $\begin{array}{c}\mathrm{DO} \\
(\mathrm{mg} / \mathrm{l})\end{array}$ & $\begin{array}{l}\text { BOD } \\
(\mathrm{mg} / \mathrm{l})\end{array}$ & $\begin{array}{l}\mathrm{COD} \\
(\mathrm{mg} / \mathrm{l})\end{array}$ & $\begin{array}{c}\mathrm{Pb} \\
(\mathrm{ppm})\end{array}$ & $\begin{array}{c}\mathrm{Ni} \\
(\mathrm{ppm})\end{array}$ & $\begin{array}{c}\mathrm{Cd} \\
(\mathrm{ppm})\end{array}$ & $\begin{array}{c}\mathrm{Cu} \\
(\mathrm{ppm})\end{array}$ \\
\hline \multirow{5}{*}{ 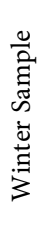 } & WBT1 & 26.6 & 1064 & 270 & 210 & 48.60 & 7.94 & 6.31 & 0.82 & 219 & BDL & 0.2678 & BDL & BDL \\
\hline & WBT2 & 26.4 & 1255 & 250 & 885 & 34.30 & 7.64 & 6.43 & 0.98 & 139 & 0.527 & 0.0697 & BDL & BDL \\
\hline & WFB3 & 26.8 & 949 & 230 & 235 & 91 & 7.18 & 6.37 & 1 & 286 & BDL & $\mathrm{BDL}$ & BDL & BDL \\
\hline & WFB4 & 26.3 & 1259 & 300 & 465 & 145.26 & 7.68 & 5.54 & 0.22 & 231 & 0.0773 & BDL & BDL & BDL \\
\hline & WFB5 & 26.2 & 903 & 210 & 850 & 126.09 & 7.75 & 5.56 & 0.24 & 229 & 0.0771 & BDL & BDL & BDL \\
\hline \multirow{5}{*}{ 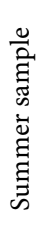 } & SBT1 & 33.3 & 1159 & 290 & 640 & 40.60 & 7.52 & 4.22 & 3.98 & 1315 & BDL & 0.0217 & BDL & 0.0385 \\
\hline & SBT2 & 33 & 1075 & 310 & 435 & 139 & 7.24 & 4.50 & 3.54 & 1083 & BDL & 0.065 & BDL & 0.0326 \\
\hline & SFB3 & 32.5 & 789 & 290 & 665 & 11.02 & 7.02 & 3.98 & 2 & 473 & BDL & 0.0226 & BDL & 0.1195 \\
\hline & SFB4 & 32.3 & 1090 & 310 & 165 & 260 & 7.33 & 4.05 & 4.05 & 720 & $\mathrm{BDL}$ & 0.0235 & $\mathrm{BDL}$ & $\mathrm{BDL}$ \\
\hline & SFB5 & 32.50 & 1082 & 300 & 850 & 26.32 & 7.29 & 4.02 & 4.02 & 1371 & BDL & 0.0706 & BDL & 0.0429 \\
\hline
\end{tabular}


TVBC of different sampling stations is presented in Table 2. The counts were extended from $3 \times 10^{6}$ to $1.8 \times 10^{7} \mathrm{cfu} / \mathrm{ml}$ in the winter season and $8 \times 10^{6}$ to 5.6 $\times 10^{7} \mathrm{cfu} / \mathrm{ml}$ in the summer season.

\subsection{Isolation and Characterization of the Heavy Metal Resistant Isolates}

Isolates from the five different sources in both winter and summer seasons were characterized (Figure 1, Figure 2). The phenotypic characterization and their tentative identification ware based on biochemical test such as Gram staining, kligler iron agar (KIA) test, indole production, methyl red (MR), voges proskauer (VP) test, Citrate utilization test, oxidase and catalase test are presented in Table 3 and Table 4. Based on these characteristics, 13 genera of bacteria were identified. Among these were probably members of the genus Pseudomonas sp., Alcaligenes sp., Bacillus sp., Staphylococcus sp., Enterobacter sp., Escherichia sp., Shigella sp., Salmonella sp., Paenibacillus sp., Micrococcus sp., Klebsiella sp., Proteus sp. and Burkholderia sp.

\subsection{Metal Tolerance Assay of the Isolates}

Heavy metal resistance profile of the isolated bacteria is depicted on Table 5 and Figure 3.

To determine the relationship of heavy metal resistance among winter and summer season, Fisher's Exact Test was accomplished and the test results were analyzed to determine the significance in a scale of $P$ value $<0.05$ (Table 6). From the analysis we could say that there is no correlation between seasonal variability

Table 2. Seasonal variation of total bacterial load at different sampling station.

\begin{tabular}{ccc}
\hline \multirow{2}{*}{ Sample ID } & \multicolumn{2}{c}{ Total viable bacterial count (TVBC) cfu/ml } \\
\cline { 2 - 3 } 1 & Winter & Summer \\
\hline 2 & $5 \times 10^{6}$ & $5.6 \times 10^{7}$ \\
3 & $1.8 \times 10^{7}$ & $1.1 \times 10^{7}$ \\
4 & $3 \times 10^{6}$ & $8 \times 10^{6}$ \\
5 & $1.4 \times 10^{7}$ & $1.7 \times 10^{7}$ \\
\end{tabular}

Table 3. Biochemical characteristics of Winter isolates.

\begin{tabular}{|c|c|c|c|c|c|c|c|c|c|c|c|c|}
\hline \multirow{2}{*}{$\begin{array}{l}\text { Presumptive } \\
\text { Organism }\end{array}$} & \multirow{2}{*}{ Frequency } & \multirow{2}{*}{$\begin{array}{c}\text { Gram } \\
\text { Staining }\end{array}$} & \multicolumn{4}{|c|}{ IMViC } & \multirow{2}{*}{ Catalase } & \multirow{2}{*}{ Oxidase } & \multicolumn{4}{|c|}{ KIA } \\
\hline & & & Indole & MR & VP & Citrate & & & Slant & Butt & $\mathrm{H} 2 \mathrm{~S}$ & Gas \\
\hline Staphylococcus sp. & 11 & + & - & + & - & - & - & + & Yellow & Yellow & - & - \\
\hline Micrococcus sp. & 4 & + & - & - & - & - & + & + & Red & Red & - & - \\
\hline Bacillus sp. & 11 & + & - & + & - & - & - & + & Red & Red & - & - \\
\hline Shigella sp. & 7 & - & - & - & - & - & - & + & Red & Red & - & - \\
\hline Escherichia sp. & 9 & + & - & - & - & - & - & + & Red & Red & - & - \\
\hline
\end{tabular}


Table 4. Biochemical characteristics of summer isolates.

\begin{tabular}{|c|c|c|c|c|c|c|c|c|c|c|c|c|}
\hline \multirow{2}{*}{$\begin{array}{c}\text { Presumptive } \\
\text { Organism }\end{array}$} & \multirow{2}{*}{ Frequency } & \multirow{2}{*}{$\begin{array}{c}\text { Gram } \\
\text { Staining }\end{array}$} & \multicolumn{4}{|c|}{ IMViC } & \multirow{2}{*}{ Catalase } & \multirow{2}{*}{ Oxidase } & \multicolumn{4}{|c|}{ KIA } \\
\hline & & & Indole & MR & VP & Citrate & & & Slant & Butt & $\mathrm{H} 2 \mathrm{~S}$ & Gas \\
\hline Klebsiella sp. & 3 & - & - & + & - & - & + & + & Red & Yellow & - & - \\
\hline Proteus sp. & 3 & - & - & + & + & + & - & + & Red & Red & - & - \\
\hline Paenibacillus sp. & 6 & + & - & + & - & - & - & + & Red & Yellow & - & - \\
\hline Enterobacter sp. & 5 & - & - & - & + & - & - & + & Red & Yellow & - & - \\
\hline Pseudomonas sp. & 11 & - & - & - & - & + & + & + & Red & Yellow & + & - \\
\hline Burkholderia sp. & 7 & - & - & - & - & + & - & + & Red & Yellow & + & - \\
\hline Salmonella sp. & 3 & - & - & + & - & + & - & + & Red & Yellow & + & - \\
\hline Bacillus sp. & 5 & - & - & - & + & + & - & + & Red & Yellow & + & - \\
\hline Alcaligenes sp. & 8 & - & - & - & - & - & + & + & Red & Red & - & - \\
\hline
\end{tabular}

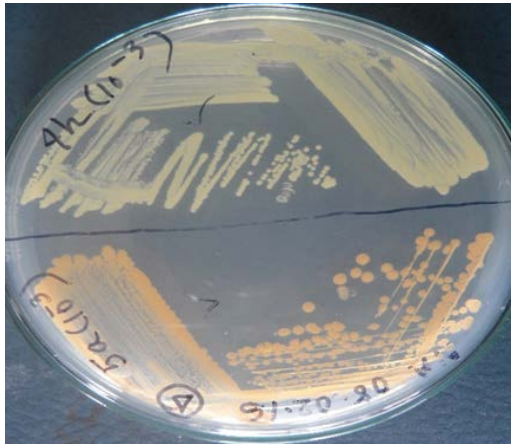

(a)

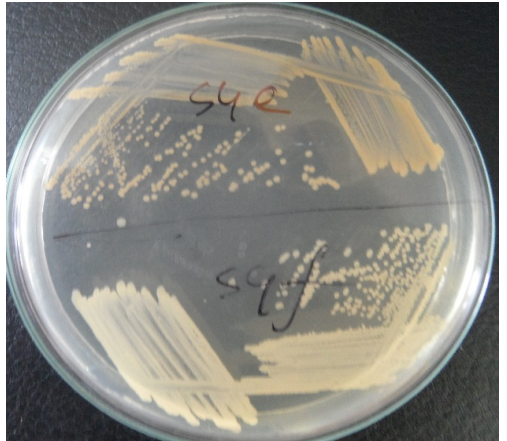

(b)

Figure 1. Representative isolates on nutrient agar plates, (a) Winter isolates (WFB4h \& WFB5a); (b) Summer isolates (SFB4e \& SFB4f).

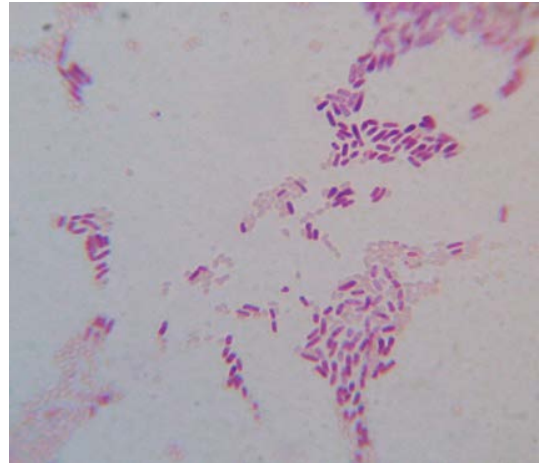

(a)

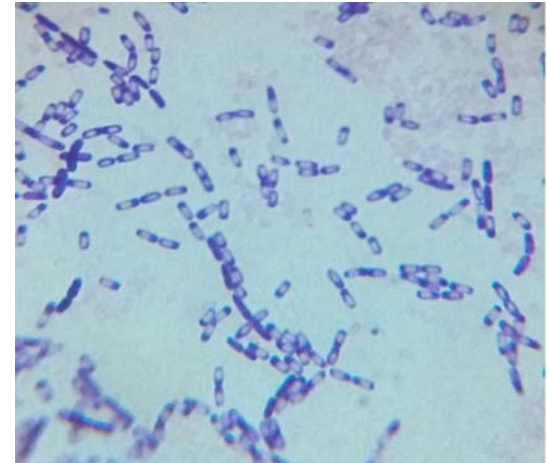

(b)

Figure 2. Microscopic observation of representative isolates, (a) Gram (-ve) WFB4i; (b) Gram (+ve) WFB4M.

in metal resistance.

\subsection{Dye Decolorization}

Methyl red dye (1\%) was used to check the decolorization ability of the isolates 


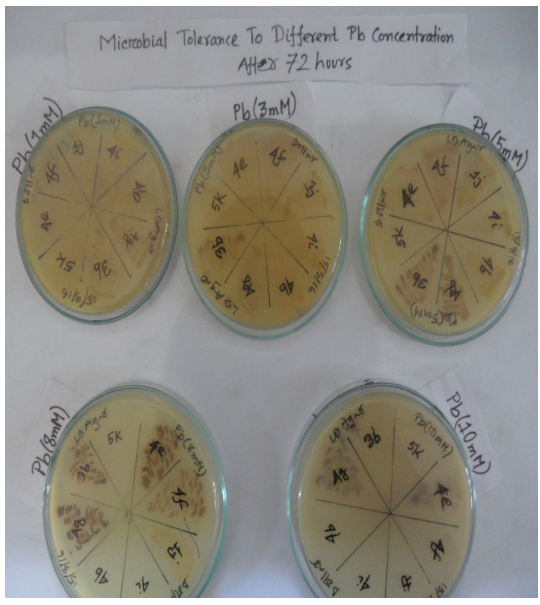

(a)

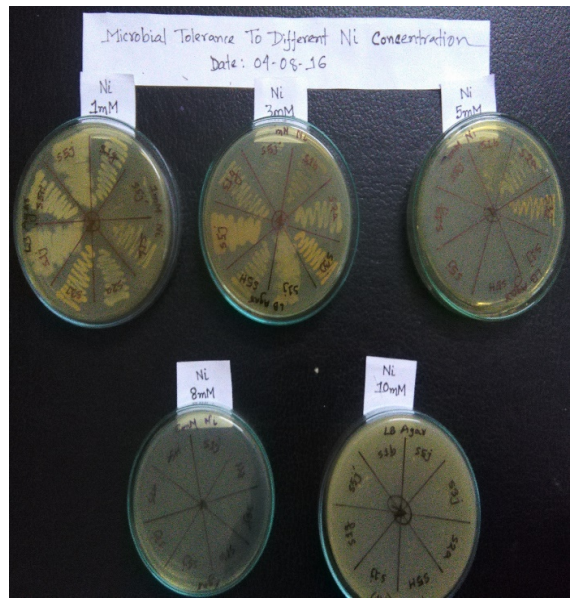

(b)

Figure 3. Metal tolerance assay of representative isolates on Luria Bertani (LB) agar plate, (a) supplemented with different concentration of lead nitrate $\left[\mathrm{Pb}\left(\mathrm{NO}_{3}\right)_{2}\right]$; (b) supplemented with different concentration of nickel chloride $\left(\mathrm{NiCl}_{2} \cdot 6 \mathrm{H}_{2} \mathrm{O}\right)$.

Table 5. Frequency of heavy metal resistant bacteria at various concentration.

\begin{tabular}{|c|c|c|c|c|c|c|c|c|c|c|}
\hline \multirow{2}{*}{$\begin{array}{l}\text { Heavy } \\
\text { Metal }\end{array}$} & \multicolumn{2}{|c|}{$1 \mathrm{mM}$} & \multicolumn{2}{|c|}{$3 \mathrm{mM}$} & \multicolumn{2}{|c|}{$5 \mathrm{mM}$} & \multicolumn{2}{|c|}{$8 \mathrm{Mm}$} & \multicolumn{2}{|c|}{$10 \mathrm{mM}$} \\
\hline & Winter & Summer & Winter & Summer & Winter & Summer & Winter & Summer & Winter & Summer \\
\hline $\mathrm{Ni}$ & 45 & 47 & 2 & 36 & 0 & 19 & 0 & 0 & 0 & 0 \\
\hline $\mathrm{Cu}$ & 45 & 47 & 2 & 36 & 0 & 19 & 0 & 0 & 0 & 0 \\
\hline $\mathrm{Pb}$ & 47 & 44 & 39 & 43 & 39 & 39 & 18 & 19 & 8 & 3 \\
\hline $\mathrm{Cd}$ & 4 & 12 & 1 & 0 & 0 & 0 & 0 & 0 & 0 & 0 \\
\hline
\end{tabular}

Table 6. Fisher's exact test.

\begin{tabular}{|c|c|c|c|c|c|}
\hline \multirow{3}{*}{ Heavy Metal } & \multicolumn{4}{|c|}{ Frequency } & \multirow{3}{*}{$\begin{array}{l}p \text { value } \\
(<0.05)\end{array}$} \\
\hline & \multicolumn{2}{|c|}{ Winter } & \multicolumn{2}{|c|}{ Summer } & \\
\hline & Positive & Negative & Positive & Negative & \\
\hline $\mathrm{Ni}$ & 45 & 49 & 47 & 47 & 0.88 \\
\hline $\mathrm{Cu}$ & 45 & 49 & 47 & 47 & 0.88 \\
\hline $\mathrm{Pb}$ & 47 & 47 & 44 & 50 & 0.0645 \\
\hline $\mathrm{Cd}$ & 4 & 90 & 12 & 82 & 0.7705 \\
\hline
\end{tabular}

(Figure 4). Two isolates from the winter sample, WFB3c \& WFB4g indicated highest decolorization ability of $65.41 \%$ \& $62 \%$ correspondingly. Among the summer isolates, SFB5c showed the highest decolorizing ability of $60.07 \%$.

\subsection{Molecular Identification}

WFB3c strains was belonged to genera Proteus. Sequence analysis revealed that the strain showed 98\% similarity with Proteus mirabilis (Figure 5). The following sequence was deposited in NCBI database with the accession number KY070340. 


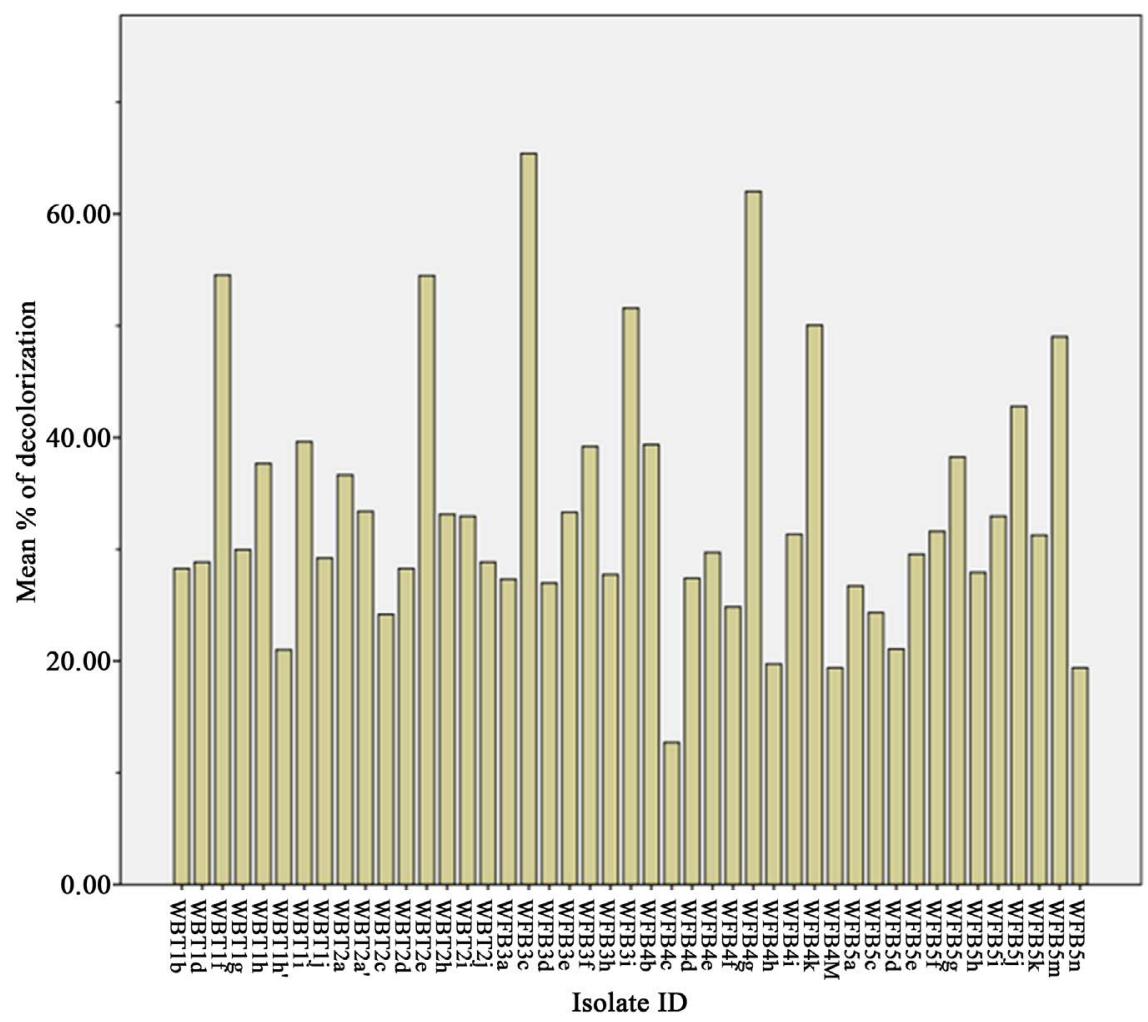

(a)

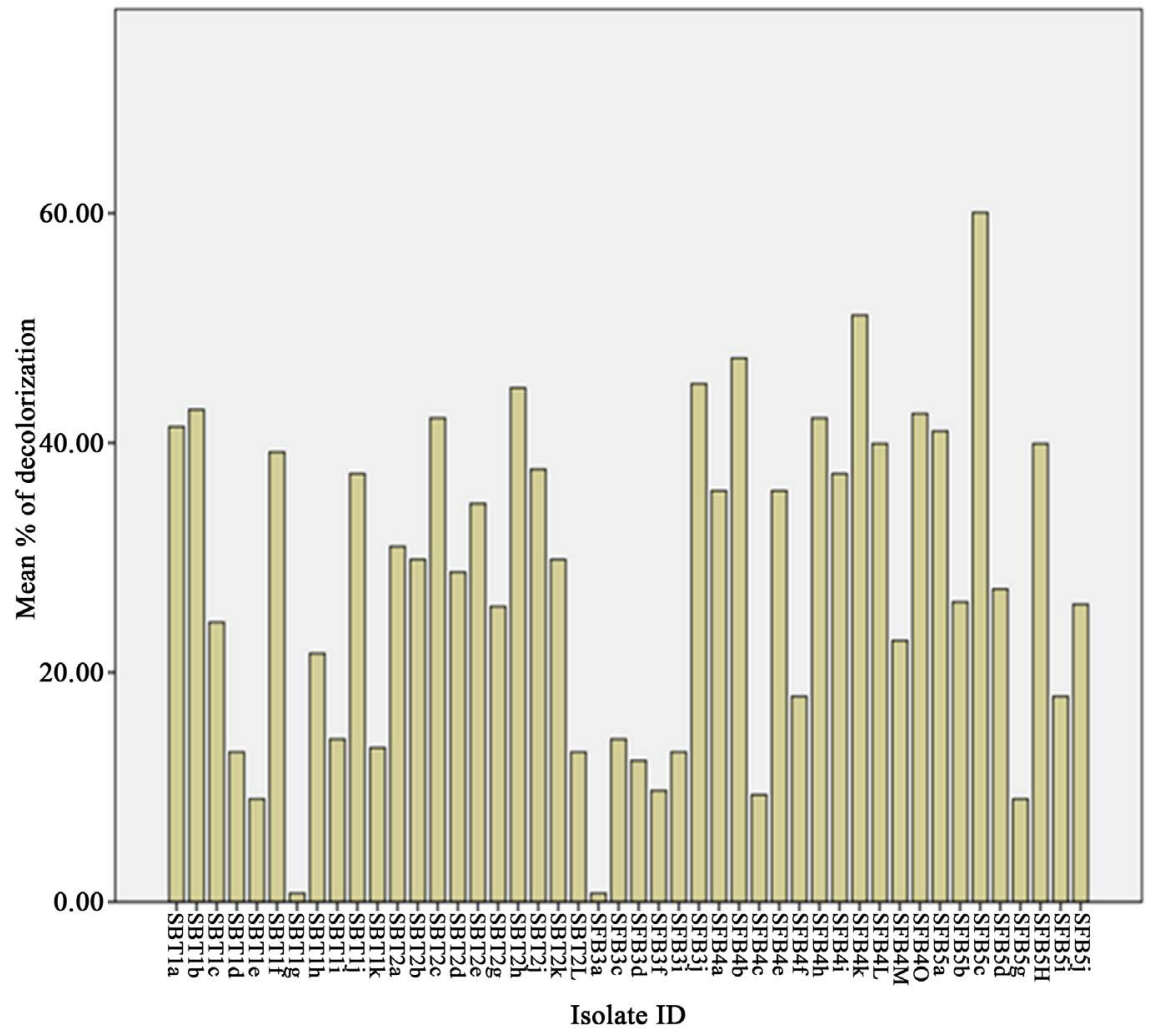

(b)

Figure 4. Methyl red degradation efficiency of the (a) winter season isolates and (b) summer season isolates. 


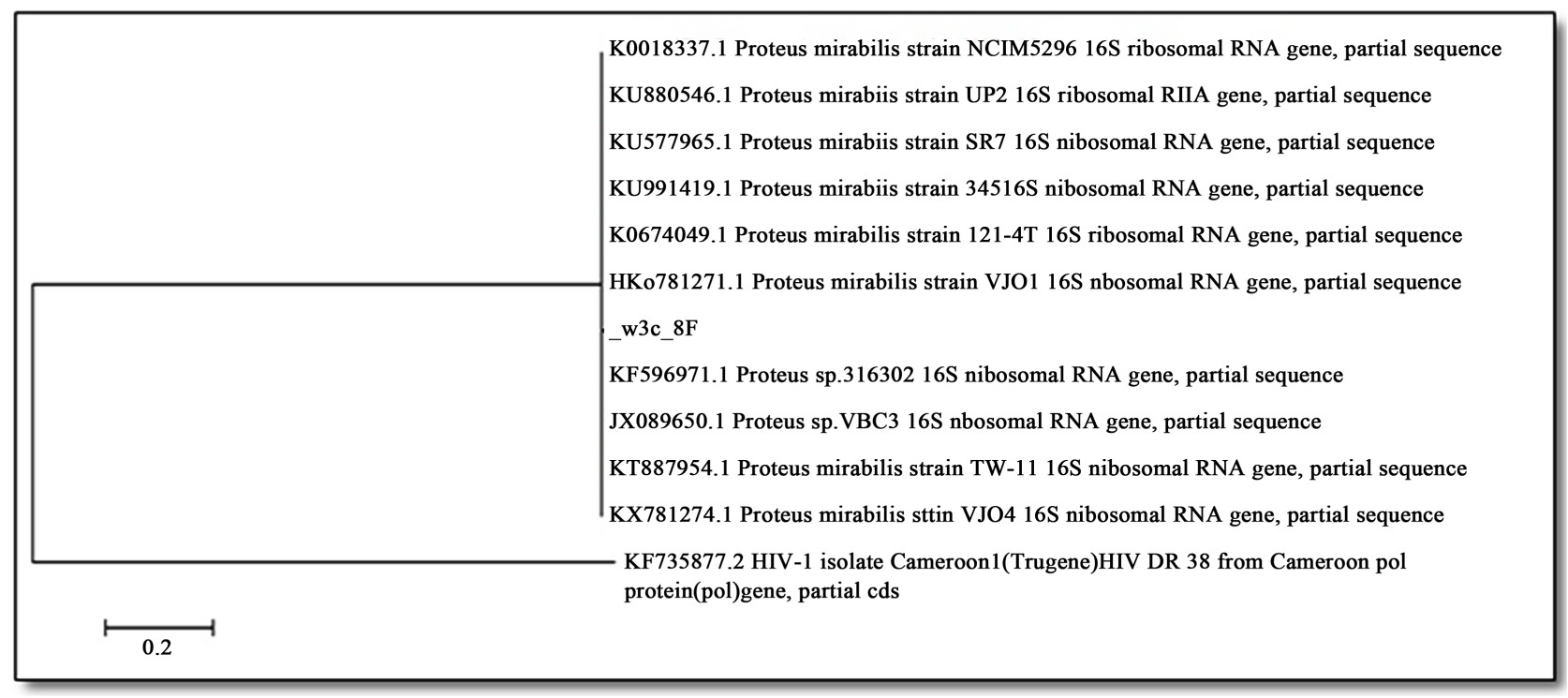

Figure 5. Phylogenetic tree of 16S rRNA gene sequences of Dye Decolorizing isolate and close relative reference isolates retrieved from database with accession number.

\section{Discussion}

The textile industries are especially problematic among the various industrial sectors as they produce substantial quantities of wastewater which could have detrimental consequences if released into the environment without any treatment. The environmental issues associated with textile activities are largely concerned due to the extensive use of dyes and various heavy metals [19]. Different physical and chemical methods for remediation of textile dyes and heavy metals are inefficient. These methods are too costly in aspect of developing country like Bangladesh [20, 21]. Developing efficient and environmental friendly technique to remove heavy metals and textile dyes is of great importance. Application of indigenous microbial community is a suitable alternative for heavy metal bioremediation [22] and azo dye biodegradation [23] from the environment.

Momentous seasonal variation was observed in the physicochemical parameters of the textile effluents. Table 1 represents the physico-chemical parameters of the water column such as BOD, COD, DO, EC, $\mathrm{pH}$, temperature, turbidity etc. The physicochemical parameters are very important as they influence the water quality considerably. Furthermore, aquatic life also suffers due to water quality depletion.

Temperature is one of the most significant ecological factors which controls the organisms' physiological behavior and distribution of the organisms [24]. The average temperature of the textile effluent was observed $32.7^{\circ} \mathrm{C}$ during the summer season and $26.5^{\circ} \mathrm{C}$ during the winter season. This is the recommended limit for no risk water quality guidelines for domestic use [25]. Temperature value was found from $48^{\circ} \mathrm{C}$ to $59^{\circ} \mathrm{C}$ in the textile effluent in Dhaka Export Processing Zone (DEPZ) area [26]. The total concentration of charged ionic species in water is usually indicated by electrical conductivity (EC) value. The measured EC value 
of this study (789 to $1259 \mu \mathrm{s} / \mathrm{cm}$ ) was found lower than the average values of $4542.50 \mu \mathrm{s} / \mathrm{cm}$ reported in Bangladesh [27]. The standard value of EC is 1200 $\mu \mathrm{s} / \mathrm{cm}$ [28]. In another report it was reported from 2250 to $19,000 \mu \mathrm{s} / \mathrm{cm}$ in the textile effluent in DEPZ area [26]. The total study area reveals the high EC except the sample 3 in summer season $(789 \mu \mathrm{s} / \mathrm{cm})$. High EC shows that large amounts of ionic substances such as sodium, iron, potassium etc. which are present in the industrial effluents are similarly found in the effluent of textile [29]. The use of electrolytes (sodium sulfate) in the bleaching process and the use of sodium carbonate and salt in the dyeing process cause an increase in the EC value of the wastewater [30].

The total dissolved solids (TDS) primarily indicates the presence of various forms of minerals such as ammonia, alkalis, nitrate, nitrite, phosphate, some acids, sulphate and metallic ions etc. that containing both dissolved solids and colloidal in water. Also, it is a significant chemical parameter of water [29]. The TDS value of the study area was lied from 210 and $310 \mathrm{mg} / \mathrm{L}$. The present findings acknowledged another study [31]. The TDS value was found 855 to 1315 $\mathrm{mg} / \mathrm{L}$ in the textile effluent in DEPZ area [26]. It was observed from the result that the total suspended solids (TSS) value ranged from 165 to $885 \mathrm{mg} / \mathrm{L}$ and all the samples were above the standard $\operatorname{DoE}(150 \mathrm{mg} / \mathrm{L})$ value of wastewater permitted to emit in inland surface water [28]. On the contrary, the TSS value in the textile effluent in DEPZ area was found from 6.20 to $175 \mathrm{mg} / \mathrm{L}$ [26].

The textile effluent turbidity was correspondingly monitored. It was varied from 11.02 FTU to 260 FTU. Average turbidity was high in summer (95.39 FTU) than winter (89.05 FTU). The turbidity value obtained from the effluent of both of the seasons was higher than standards of World Health Organization (WHO) [32]. The $\mathrm{pH}$ value in this study ranged from 7.02 to 7.94 (slightly alkaline) within the acceptable limit for different uses such as irrigation, domestic and recreational, according to the standard DoE value ( $\mathrm{pH} 6$ to 9) [28]. The $\mathrm{pH}$ value of the textile effluent in the DEPZ area was found from 7.20 to 10.30 [26]. The standard range of $\mathrm{pH}$ for surface water and for groundwater systems is from 6.5 to 8.50 and from 6 to 8.50 correspondingly in accordance with Environmental Conservation Rules, 1997 [33]. The average $\mathrm{pH}$ values were reported 8.18 in textiles effluents in Bangladesh [34]. The $\mathrm{pH}$ parameter not only greatly affects biological activity but also affects some properties of water body, activity of organism and effectiveness of toxic substances present in the aquatic environment. To determine the corrosiveness of the water, measurement of $\mathrm{pH}$ value is needed [29].

The another important parameter, dissolved oxygen (DO) value was found from 3.98 to $6.43 \mathrm{mg} / \mathrm{L}$. According to standard the effluent should contain DO $4.80-8 \mathrm{mg} / \mathrm{L}$ [28]. The DO value was found from 2.15 to $5.90 \mathrm{mg} / \mathrm{L}$ in the textile effluent in DEPZ area [26]. In biological oxygen demand (BOD) value the seasonal variation ranged from 0.22 to $4.05 \mathrm{mg} / \mathrm{L}$. During the summer season the observed BOD value was higher than in the winter season. The permissible limit for BOD for industrial effluent is $50 \mathrm{mg} / \mathrm{L}$ [31]. In this study, the BOD value was 
observed below than the standard and it might indicate good quality of the effluent. The BOD value was found ranging from 94.33 to $141.66 \mathrm{mg} / \mathrm{L}$ in the textile effluent of DEPZ area in a previous study [26].

The value of chemical oxygen demand (COD) was found above the standard $(200 \mathrm{mg} / \mathrm{L})$ both in winter and summer season, except in WBT2 a winter sample with value of $139 \mathrm{mg} / \mathrm{L}$ [28]. The remarkable rise in COD levels compared with BOD also suggests that there might be significant levels of toxicants e.g. the heavy metals might possibly be present into the wastewater [35]. The COD value was reported 170.88 to $854.40 \mathrm{mg} / \mathrm{L}$ in the textile effluent in DEPZ area [26].

Heavy metals are highly toxic and so can cause detrimental effects even at very low concentration. Metals usually arise from dye stripping agents, metal complex dyes, oxidizing agents and finishers in textile effluent [36]. In our study $\mathrm{Pb}$ and $\mathrm{Ni}$ were found in winter season but $\mathrm{Ni} \& \mathrm{Cu}$ in summer season. On the contrary, in this study $\mathrm{Cd}$ was not found in both seasons. In a study conducted in a textile industry of Savar area except $\mathrm{Cu}, \mathrm{Pb}$ and $\mathrm{Cd}$ was not found in both seasons [27]. In the following investigation, the measured concentrations of heavy metals $(\mathrm{Cd}, \mathrm{Cu}, \mathrm{Pb}$ and $\mathrm{Ni}$ ) are lower than the permissible limit of wastewater discharge standards according to DoE (2008). If heavy metals are found beyond permissible limits in water may be toxic to human beings, aquatic flora and fauna. It is quite evident that these heavy metals may enter the food chain, and through bioaccumulation and bio-magnifications can easily reach humans through plants and can cause various deadly diseases [37].

Total viable bacterial count (TBVC) is one of the important parameters for determining water quality [38]. In monitoring different types of pollutants, the total bacterial count may provide extremely valuable statistics. It has long been reported that bacteria inhabit in industrial effluent utilizing its constituents as their source of energy. Similarly, the textile effluent that has been analysis in our study was appeared to harbor a significant number of bacteria. In this study, the average bacterial load was found $1.6 \times 10^{7} \mathrm{cfu} / \mathrm{ml}$ that was determined by TBVC method and was performed by serial dilution of the effluent and subsequent inoculation onto nutrient agar medium, similar to another previous study [39]. The high bacterial counts reflect that the textile dyeing effluents remain good sources of nutrients to facilitate the growth of certain bacteria [40].

It was found that seasonal variation is an important factor which influences in microbial distribution, similar to another previous study [41]. They found that the seasonal cycle of the organism was correlated with the winter and summer seasons and the highest numbers were found in the summer season. In this present investigation, the impact of seasonal variations in TBVC was observed. There were significant changes in the total viable bacterial count in summer season (average $2.24 \times 10^{7}$ ) as compare to winter season (average $8.64 \times 10^{6}$ ). The temperature of the summer season might higher microbial growth.

The characterization of microbial diversity is the first step for any sort of understanding of a system, either its function or applications [42]. In the present study, 13 different bacterial genera were isolated and identified from the textile 
dye effluent. The isolated bacterial isolates were presumptively identified and characterized by biochemical tests as Pseudomonas sp., Alcaligenes sp., Bacillus sp., Staphylococcus sp., Enterobacter sp., Escherichia sp., Shigella sp., Salmonella sp., Paenibacillus sp., Micrococcus sp., Klebsiella sp., Proteus sp. and Burkholderia sp., this finding of the present study is consistent with some other previous studies [42-44].

Heavy metal contamination in aquatic environment is an emerging quality issue for developing countries like Bangladesh [1]. Exposure of xenobiotic compounds such as textile dyes, heavy metals to the environment i.e., microbial habitat, facilitated development of various resistance mechanism for the adaptation to this environment. These mechanisms could be used to detoxify \& degrade of heavy metals and textile dyes into simpler form from the polluted environment $[1,45]$. Biological treatment of wastewater through microbial activities might be an active field of research.

For the treatment of industrial waste water containing heavy metals, it is necessary to test the ability of the organisms to grow in the presence of heavy metal is very crucial [46]. In present study, all the 94 isolates were tested to determine their ability to grow in the presence of cadmium $(\mathrm{Cd})$, cupper $(\mathrm{Cu})$, lead $(\mathrm{Pb})$ and nickel (Ni) at different concentrations $(1 \mathrm{mM}, 3 \mathrm{mM}, 5 \mathrm{mM}, 8 \mathrm{mM} \& 10$ $\mathrm{mM})$. All the isolates could tolerate lead, $92 \& 58$ isolate were shown to tolerance nickel \& cupper respectively and in case of cadmium it was observed that only 16 isolate could tolerate it. It was observed that cadmium was toxic, nickel \& cupper was moderately toxic for most of the studied isolates above $1 \mathrm{mM}$ concentration (Table 5 \& Table 6). Microorganisms have acquired different types protective mechanisms to thrive in very high levels of lead. Among the various adaptive mechanisms adopted by lead resistant microorganisms include: P-type ATPase mediated efflux of lead [47].

In this study, it was found that 17 isolates were observed to tolerate all the tested heavy metals $(\mathrm{Pb}, \mathrm{Ni}, \mathrm{Cd} \& \mathrm{Cu})$. A study was conducted in 2012 and they isolated an organism belonging to the Bacillus sp. having the ability to grow in presence of a wide range of metals namely nickel, cadmium, chromium and cobalt in the order $\mathrm{Cd}^{2+}>\mathrm{Cr}^{6+}>\mathrm{Ni}^{2+}>\mathrm{Co}^{2+}$ [48]. Multiple metal resistant $\left(\mathrm{Hg}^{2+}\right.$, $\mathrm{Pb}^{2+}, \mathrm{Cd}^{2+}, \mathrm{As}^{5+}$ and $\mathrm{Cr}^{6+}$ ) isolates were also found in another investigation [49]. Genomic analysis will reveal the exact mechanism of developing resistance of studied isolates.

Azo dyes like methyl red are known to be major human carcinogens besides being environmental damage [50]. As a result, dye decolorization has been a primary focus of dye wastewater treatment processes. There are several physicochemical methods for dye removal from colored effluents that are not suitable due to some limitations such as handling of produced sludge, high cost etc. [51]. Currently biological decolorization method is both competitive and alternative to conventional method [52]. There are several reports on isolation of dye decolorizing bacteria, fungi and yeast [53]. In this study, three bacteria were isolated having potentiality of dye decolorizing. Among them, two [WFB4g (62\%) \& 
WFB3c (65.41\%)] from winter season and one [SFB5c (60.07\%)] from the summer season.

From these isolates, one (WFB3c) was found to be highly potential dye decolorizer and was identified as Proteus mirabilis according to $16 \mathrm{~S}$ rRNA sequence [accession number KY070340]. In another study, Proteus mirabilis decolorizes dye under anoxic conditions while in some cases they require additional carbon sources to decolorize since they are unable to utilize the dyes due to their toxicity [54]. So, these isolate may be used in the biological treatment of industrial effluent containing methyl red dye. Further molecular characterization will be carried out in the future in order to fully appreciate the azo dye decolorizing ability of these isolates.

\section{Conclusion}

Further molecular investigation of these bacterial strains could make them potential candidates for dye degradation of textile industries in Bangladesh. The metal resistance capability of these isolates might offer a beneficial tool for the simultaneous monitoring of many contaminants and pollutants in the environment. Therefore, in details study of these isolates is needed for their optimization and implementation in the treatment plant of textile industries.

\section{Acknowledgements}

The work has been supported by grants from the University Grants Commission (UGC) and Jahangirnagar University. Authors would like to thank Mr. Nikhil Chandra Bhoumik of Wazed Mia Center of Excellence, Jahangirnagar University for detection of metal contents of the samples.

\section{Conflicts of Interest}

The authors do not have any conflicts of interest or financial disclosures to report.

\section{References}

[1] Ahmed, M.K., Baki, M.A., Islam, M.S., Kundu, G.K., Habibullah-Al-Mamun, M., Sarkar, S.K. and Hossain, M.M. (2015) Human Health Risk Assessment of Heavy Metals in Tropical Fish and Shellfish Collected from the River Buriganga, Bangladesh. Environmental Science and Pollution Research, 22, 15880-15890. https://doi.org/10.1007/s11356-015-4813-Z

[2] Islam, M.S., Ahmed, M.K., Raknuzzaman, M., Habibullah-Al-Mamun, M. and Islam, M.K. (2015) Heavy Metal Pollution in Surface Water and Sediment: A Preliminary Assessment of an Urban River in a Developing Country. Ecological Indicators, 48, 282-291. https://doi.org/10.1016/j.ecolind.2014.08.016

[3] Khan, M., Alam, M., Islam, M., Hassan, M. and Al-Mansur, M. (2011) Environmental Pollution around Dhaka EPZ and Its Impact on Surface and Groundwater. Bangladesh Journal of Scientific and Industrial Research, 46, 153-162. https://doi.org/10.3329/bjsir.v46i2.8181

[4] Fakayode, S.O. (2005) Impact Assessment of Industrial Effluent on Water Quality of 
the Receiving Alaro River in Ibadan, Nigeria. African Journal of Environmental Assessment and Management, 10, 1-13. https://africabib.org/s/htp.php

[5] Jadhav, J.P., Phugare, S.S., Dhanve, R.S. and Jadhav, S.B. (2010) Rapid Biodegradation and Decolorization of Direct Orange 39 (Orange TGLL) by an Isolated Bacterium Pseudomonas aeruginosa Strain BCH. Biodegradation, 21, 453-463. https://doi.org/10.1007/s10532-009-9315-6

[6] Al-Musharafi, S., Mahmoud, I. and Al-Bahry, S. (2012) Heavy Metal Contamination from Treated Sewage Effluents. WIT Transactions on Ecology and the Environment, 164, 381-389. https://doi.org/10.2495/WP120331

[7] Cripps, C., Bumpus, J.A. and Aust, S. (1990) Biodegradation of Azo and Heterocyclic Dyes by Phanerochaete chrysosporium. Applied and Environmental Microbiology, 56, 1114-1118. https://doi.org/10.1128/AEM.56.4.1114-1118.1990

[8] Moreira, M.T., Viacava, C. and Vidal, G. (2004) Fed-Batch Decolorization of Poly R-478 by Trametes Versicolor. Brazilian Archives of Biology and Technology, 47, 179-183. https://doi.org/10.1590/S1516-89132004000200003

[9] Spadaro, J.T., Gold, M.H. and Renganathan, V. (1992) Degradation of Azo Dyes by the Lignin-Degrading Fungus Phanerochaete chrysosporium. Applied and Environmental Microbiology, 58, 2397-2401.

https://aem.asm.org/content/aem/58/8/2397 https://doi.org/10.1128/AEM.58.8.2397-2401.1992

[10] Kapdan, I.K., Kargi, F., McMullan, G. and Marchant, R. (2000) Decolorization of Textile Dyestuffs by a Mixed Bacterial Consortium. Biotechnology Letters, 22, 11791181. https://doi.org/10.1023/A:1005641430613

[11] Barka, N., Abdennouri, M. and Makhfouk, M.E. (2011) Removal of Methylene Blue and Eriochrome Black T from Aqueous Solutions by Biosorption on Scolymus hispanicus L.: Kinetics, Equilibrium and Thermodynamics. Journal of the Taiwan Institute of Chemical Engineers, 42, 320-326. https://doi.org/10.1016/j.jtice.2010.07.004

[12] Rajaguru, P., Vidya, L., Baskarasethupathi, B., Kumar, P.A., Palanivel, M. and Kalaiselvi, K. (2002) Genotoxicity Evaluation of Polluted Ground Water in Human Peripheral Blood Lymphocytes Using the Comet Assay. Mutation Research/Genetic Toxicology and Environmental Mutagenesis, 517, 29-37. https://doi.org/10.1016/S1383-5718(02)00025-6

[13] McMullan, G., Meehan, C., Conneely, A., Kirby, N., Robinson, T., Nigam, P., Banat, I., Marchant, R. and Smyth, W.F. (2001) Microbial Decolourisation and Degradation of Textile Dyes. Applied Microbiology and Biotechnology, 56, 81-87. https://doi.org/10.1007/s002530000587

[14] Salar, R.K., Rohilla, S.K. and Rohilla, J.K. (2012) Decolorization of Reactive Black HFGR by Aspergillus sulphureus. Annals of Biological Research, 3, 3811-3817. https://www.researchgate.net/publication/260952329

[15] Cappuccino, J.G.S., Cappuccino, N.J.G. and Sherman, N. (1996) Microbiology: A Laboratory Manual.

[16] Raja, E.C., Selvam, G.S. and Ominie, K. (2009) Isolation, Identification and Characterization of Heavy Metal Resistant Bacteria from Sewage. International Joint Symposium on Geodisaster Prevention \& Geoenvironment in Asia, Fukuoka, 205-211.

[17] Gee, J.E., Sacchi, C.T., Glass, M.B., DE, B.K., Weyant, R.S., Levett, P.N., Whitney, A.M., Hoffmaster, A.R. and Popovic, T. (2003) Use of 16S rRNA Gene Sequencing for Rapid Identification and Differentiation of Burkholderia pseudomallei and $B$. mallei. Journal of clinical microbiology, 41, 4647-4654. 
https://doi.org/10.1128/JCM.41.10.4647-4654.2003

[18] Larkin, M.A., Blackshields, G., Brown, N.P., Chenna, R., McGettigan, P.A., McWilliam, H., Valentin, F., Wallace, I.M., Wilm, A. and Lopez, R. (2007) Clustal W and Clustal X Version 2.0. Bioinformatics, 23, 2947-2948.

https://doi.org/10.1093/bioinformatics/btm404

[19] Peralta-Zamora, P., Pereira, C.M., Tiburtius, E.R., Moraes, S.G., Rosa, M.A., Minussi, R.C. and Durán, N. (2003) Decolorization of Reactive Dyes by Immobilized Laccase. Applied Catalysis B: Environmental, 42, 131-144. https://doi.org/10.1016/S0926-3373(02)00220-5

[20] Volesky, B. (1990) Biosorption of Heavy Metals. CRC Press, Boca Raton.

[21] Vandevivere, P.C., Bianchi, R. and Verstraete, W. (1998) Review: Treatment and Reuse of Wastewater from the Textile Wet-Processing Industry: Review of Emerging Technologies. Journal of Chemical Technology and Biotechnology, 72, 289-302. https://doi.org/10.1002/(SICI)1097-4660(199808)72:4<289::AID-JCTB905>3.0.CO;2-\#

[22] Garbisu, C. and Alkorta, I. (2001) Phytoextraction: A Cost-Effective Plant-Based Technology for the Removal of Metals from the Environment. Bioresource Technology, 77, 229-236. https://doi.org/10.1016/S0960-8524(00)00108-5

[23] Rai, H.S., Bhattacharyya, M.S., Singh, J., Bansal, T., Vats, P. and Banerjee, U. (2005) Removal of Dyes from the Effluent of Textile and Dyestuff Manufacturing Industry: A Review of Emerging Techniques with Reference to Biological Treatment. Critical Reviews in Environmental Science and Technology, 35, 219-238. https://doi.org/10.1080/10643380590917932

[24] Shirin, S. and Yadav, A.K. (2014) Physico Chemical Analysis of Municipal Wastewater Discharge in Ganga River, Haridwar District of Uttarakhand, India. Current World Environment, 9, 536. https://doi.org/10.12944/CWE.9.2.39

[25] Fatoki, O., Gogwana, P. and Ogunfowokan, A. (2003) Pollution Assessment in the Keiskamma River and in the Impoundment Downstream. Water SA, 29, 183-188. https://doi.org/10.4314/wsa.v29i2.4854

[26] Ahmed, T. (2007) Characterization of Textile Effluent from Selected Industries in DEPZ and Their Treatment by Adsorption-Filtration Process. M.Sc. Thesis, Department of Environmental Sciences, Jahangirnagar University, Dhaka, 1-132.

[27] Roy, R., Fakhruddin, A., Khatun, R., Islam, M., Ahsan, M. and Neger, A. (2010) Characterization of Textile Industrial Effluents and its Effects on Aquatic Macrophytes and Algae. Bangladesh Journal of Scientific and Industrial Research, 45, 79-84. https://doi.org/10.3329/bjsir.v45i1.5187

[28] Huq, M. (2003) A Compilation of Environmental Laws of Bangladesh. Administrated by the Department of Environment (DOE), 215-245.

[29] Kabir, E., Kabir, M., Islam, S., Mia, C., Begum, N., Chowdhury, D., Sultana, S. and Rahman, S. (2002) Assessment of the Effluent Quality of Dhaka Export Processing Zone with Special Emphasis to the Textile and Dying Industries. Jahangirnagar University Journal of Science, 25, 137-138.

[30] Adaikkalam, V. and Swarup, S. (2002) Molecular Characterization of an Operon, cueAR, Encoding a Putative P1-Type ATPase and a MerR-Type Regulatory Protein Involved in Copper Homeostasis in Pseudomonas putida. Microbiology, 148, 2857 2867. https://doi.org/10.1099/00221287-148-9-2857

[31] Rahman, A.L., Islam, M., Hossain, M. and Ahsan, M. (2012) Study of the Seasonal Variations in Turag River Water Quality Parameters. African Journal of Pure and Applied Chemistry, 6, 144-148. https://doi.org/10.5897/AJPAC12.023

[32] Morokov, V. (2001) Assessment of River Pollutant Source. 
[33] MoEF, G.O.B. (2016) Bangladesh Environment Conservation Rules, 1997.

[34] Kanan, A.H., Marine, S.S., Raihan, F., Redowan, M. and Miah, M. (2014) Textile Effluents Changes Physiochemical Parameters of Water and Soil: Threat for Agriculture. African Journal of Agronomy, 2, 219-223.

[35] Chavan, R. (2001) Environment-Friendly Dyeing Processes for Cotton. Indian Journal of Fibre and Textile Research, 26, 93-100. http://nopr.niscair.res.in/handle/123456789/24918

[36] Mountassir, Y., Benyaich, A., Rezrazi, M., Berçot, P. and Gebrati, L. (2013) Wastewater Effluent Characteristics from Moroccan Textile Industry. Water Science and Technology, 67, 2791-2799. https://doi.org/10.2166/wst.2013.205

[37] Dutta, S. and Singh, S. (2015) Seasonal Variation in Different Physico-Chemical Characteristics in Ground Water Quality of Pali Industrial Area, Rajasthan, India. International Journal Research Pharmaceutical Sciences, 5, 25-29. http://www.ijrpsonline.com

[38] Garnier, J., Servais, P. and Billen, G. (1992) Bacterioplankton in the Seine River (France): Impact of the Parisian Urban Effluent. Canadian Journal of Microbiology, 38, 56-64. https://doi.org/10.1139/m92-009

[39] Mahbub, K., Mohammad, A., Ahmed, M. and Begum, S. (2012) Decolorization of Synthetic Dyes Using Bacteria Isolated from Textile Industry Effluent. Asian Journal of Biotechnology, 4, 129-136. https://doi.org/10.3923/ajbkr.2012.129.136

[40] Mihir, L.S., Mahbubur, R. and Farida, I. (2006) Bacteria Associated with Textile Dyeing Industrial Effluents and Their Depolarization Potentiality. Bangladesh Journal of Microbiology, 23, 52-54.

[41] Neumann, D.A., Benenson, M.W., Hubster, E. and Tuan, N.T.N. (1972) Vibrio parahemolyticus in the Republic of Vietnam. The American Journal of Tropical Medicine and Hygiene, 21, 464-466. https://doi.org/10.4269/ajtmh.1972.21.464

[42] Prabha, S., Gogoi, A., Mazumder, P., Ramanathan, A.L. and Kumar, M. (2017) Assessment of the Impact of Textile Effluents on Microbial Diversity in Tirupur District, Tamil Nadu. Applied Water Science, 7, 2267-2277. https://doi.org/10.1007/s13201-016-0394-3

[43] Mahmood, R., Sharif, F., Ali, S. and Hayyat, M.U. (2015) Enhancing the Decolorizing and Degradation Ability of Bacterial Consortium Isolated from Textile Effluent Affected Area and Its Application on Seed Germination. The Scientific World Journal, 2015, Article ID: 628195. https://doi.org/10.1155/2015/628195

[44] Saranraj, P. and Sivasakthivelan, P. (2014) Prevalence of Bacterial Isolates in Textile Dye Effluentand Analysis of Its Dye Degrading Efficiency. Middle-East Journal of Scientific Research, 21, 721-725.

[45] Parales, R.E., Bruce, N.C., Schmid, A. and Wackett, L.P. (2002) Biodegradation, Biotransformation, and Biocatalysis (B3). Applied and Environmental Microbiology, 68, 4699-4709. https://doi.org/10.1128/AEM.68.10.4699-4709.2002

[46] Filali, B., Taoufik, J., Zeroual, Y., Dzairi, F., Talbi, M. and Blaghen, M. (2000) Waste Water Bacterial Isolates Resistant to Heavy Metals and Antibiotics. Current Microbiology, 41, 151-156. https://doi.org/10.1007/s0028400

[47] Nies, D.H. and Silver, S. (1995) Ion Efflux Systems Involved in Bacterial Metal Resistances. Journal of industrial microbiology, 14, 186-199. https://doi.org/10.1007/BF01569902

[48] Samanta, A., Bera, P., Khatun, M., Sinha, C., Pal, P., Lalee, A. and Mandal, A. (2012) An Investigation on Heavy Metal Tolerance and Antibiotic Resistance Properties of 
Bacterial Strain Bacillus sp. Isolated from Municipal Waste. Journal of Microbialogy \& Biotechnology Research, 2, 178-189.

https://www.researchgate.net/publication/258885867

[49] El-Sayed, M.H. (2016) Multiple Heavy Metal and Antibiotic Resistance of Acinetobacter baumanni Strain HAFC 13 Isolated from Industrial Effluents. American Journal of Microbiological Research, 4, 26-36.

[50] Hayes, B.B., Azadi, S., Sullivan, R. and Meade, B.J. (2004) Contact Hypersensitivity to Methyl Red in Female Balb/c Mice. Journal of Allergy and Clinical Immunology, 113, S57. https://doi.org/10.1016/j.jaci.2003.12.172

[51] O'neill, C., Lopez, A., Esteves, S., Hawkes, F.R., Hawkes, D.L. and Wilcox, S. (2000) Azo-Dye Degradation in an Anaerobic-Aerobic Treatment System Operating on Simulated Textile Effluent. Applied Microbiology and Biotechnology, 53, 249-254. https://doi.org/10.1007/s002530050016

[52] Moosvi, S., Keharia, H. and Madamwar, D. (2005) Decolourization of Textile Dye Reactive Violet 5 by a Newly Isolated Bacterial Consortium RVM 11.1. World Journal of Microbiology and Biotechnology, 21, 667-672.

https://doi.org/10.1007/s11274-004-3612-3

[53] Olukanni, O.D., Osuntoki, A.A. and Gbenle, G.O. (2006) Textile Effluent Biodegradation Potentials of Textile Effluent-Adapted and Non-Adapted Bacteria. African Journal of Biotechnology, 5, 1980-1984. http://www.academicjournals.org/AJB

[54] Chang, S.T., Chen, P.F. and Chang, S.C. (2001) Antibacterial Activity of Leaf Essential Oils and Their Constituents from Cinnamomum osmophloeum. Journal of Ethnopharmacology, 77, 123-127. https://doi.org/10.1016/S0378-8741(01)00273-2 